\section{FRESHWATER FISHES}

$\mathrm{T}$ HE work of the Freshwater Biological Association of the British Empire shows a large amount of activity on the part of all workers*. Naturally research on fishes takes the lead and much that is of real economic importance has been achieved. Of outstanding interest is the successful commercial perch fishery on Lake Windermere. This is an excellent example of a practical application in wartime of research carried out previously with purely scientific motives (see NATURE, 148, 651; 1941). Work on the study of the perch in Windermere was begun in 1933-35 by Mr. K. R. Allen who demonstrated by the use of traps that perch migrate into the shallows in spring. This resulted later in largescale use of traps in catching perch by the ton with little labour and on a commercial scale. A firm of canners has now marketed the canned fish as 'Perchines' which have had a very favourable reception, and from the financial point of view also the project was a success. Traps were tried on other lakes which gave good results and the Ministry of Agriculture and Fisheries has decided to organize fisheries similar to that on Windermere on six lakes, two more being arranged by private enterprise. It is possible that in some of the lakes other fish, such as eels and pike, which enter the traps in pursuit of the perch, may be an even more valuable catch. The possibility of expanding the industry to water outside the Lake District is now being explored. It is expected that the rod fisheries will be improved by the reduction in number of perch, pike and eels. In Windermere the examination of changes in the flora and fauna due to the reduction in perch is being undertaken.

Since the beginning of the War the Association, in co-operation with the Ministry of Agriculture and Fisheries, has devoted much attention to the fact that British waters could, and should, produce all the eels imported from the Continent during times of peace, and many more besides. Experiments were begun in 1941 in connexion with eel-fishery, on the use of artificial light for deflecting silver eels into traps. Although so far they are not conclusive it was confirmed that silver eels react to light more or less in the way expected, and that there are no serious practical difficulties, even in war-time, in the way of rigging lights to be seen under water by migrating eels. With one of these systems of lighting about half the eels from both natural and artificial runs swimming down one side of the stream were deflected to the other side. It was also found during these experiments, by the use of traps divided horizontally, that about one third of the eels were swimming nearer the surface than the bottom. As it is generally assumed that the migrating fish swim close to or along the bottom of rivers, this fact may be important when reconsidering the design of commercial traps.

Miss Winifred Frost has been working on various fishes and has advanced steadily our knowledge of the freshwater life of British eels. Drainage basin elvers ascending the rivers in spring, yellow eels inhabiting the lakes, and silver eels descending to the sea in autumn have all been examined. Otoliths and scales were used, although these are not truly satisfactory for age growth determination in eels above $40 \mathrm{~cm}$. in length. The results show that all

* Tenth Annual Report for the Year ending 31st March, 1942. (Ambleside: Freshwater Biological Association of the British Empire.) Pp. 40. 18. 6d. the silver eels and the great majority of yellow eels examined were female: presumably nearly all males live in or near the estuaries. About eight years of freshwater life takes place before the eels attain a length of $40 \mathrm{~mm}$. and a weight of $\frac{1}{4} \mathrm{lb}$. After that the growth varies widely until the fishes migrate to the sea as silver eels after 10-17 years of freshwater life. The silver eels range in length from $47 \mathrm{~cm}$. to 94 $\mathrm{cm}$. and in weight from $7 \mathrm{oz}$. to $4 \mathrm{lb}$. Many of the eels examined for food contained molluscs, fishes and insects. Molluscs were common in the yellow eels, which also contained minnows, perch and caddis larvæ. Some of the silver eels contained perch, minnows and caddis flies. Elvers taken from the River Leven just after their entrance into freshwater were feeding heavily on chironomid larvæ-a common food of the trout.

Miss Frost's work on minnows shows that they are important competitors for food with young perch and trout, while although the char and the young perch are both plankton feeders they usually eat different species.

Artificial fertilization of char eggs and rearing of fry are being carried out at Wragmere fish hatchery. The fry are reared more easily than the trout until the complete absorption of the yolk, but after that they present difficulties in the fry ponds. It is hoped to rear the fry in boxes in the lake where natural plankton food will be available. Growth-rate and feeding habits in the trout from different localities are being studied and successful cross fertilizations have been made between brown trout, Windermere char and the American brook trout or char.

\section{RADIO RESEARCH}

T $\mathrm{N}$ his inaugural address as chairman of the Wireless Section of the Institution of Electrical Engineers, delivered on October 7, Dr. R. L. Smith-Rose dealt first with the history and growth of the Wireless Section, then with the work of the Radio Research Board; and finally he presented a survey of the present state of our knowledge of the speed of travel of electric waves of all wave-lengths from the visual to the radio-frequency spectrum (the substance of this last section appears on p. 477).

The Wireless Section of the Institution is just over twenty-three years old, in which time its membership has grown to more than eleven hundred. The Section has held 163 formal meetings, at which addresses and papers have been delivered, while informal meetings have been arranged from time to time to discuss topical technical subjects. In 1926 a report presented to the Council of the Institution by the committee of the Wireless Section referred to a proposal which was then being mooted in some quarters to form a new Institute of Wireless Engineers. The report suggested that such a step was unnecessary and would not be supported by representative and qualified wireless engineers. It was explained that an engineer with adequate wireless qualifications could become a corporate member of the Institution, and that other wireless engineers not reaching that standard were eligible as graduates, and as such could attend all meetings of the Wireless Section as well as of the Institution. Furthermore, the committee recommended that while it was essential that the standard of qualifications for membership of the Institution should be maintained, 
more opportunity should be afforded to the physicist engaged in wireless work to become a member of the Institution. This recommendation was approved by the Council and has continuously been acted upon by the committees responsible for electing new members; it is particularly opportune to direct attention to it at the present time, when a large number of men engaged on wireless work would probably refer to themselves as radio physicists rather than wireless or radio engineers.

Among other recommendations made in the report referred to above was one to the effect that all papers and discussions of a wireless nature should be published in a separate Proceedings of the Wireless Section as well as in the Journal of the Institution. For this every member of the Wireless Section must be very grateful. Fifteen volumes of these Proceedings were published during the period 1926-40, and these contain a most valuable record of the progress of wireless engineering research and development in a very compact form and free from the large mass of other papers published by the Institution and in which the wireless engineer has little more than general or passing interest. With the revision of the form of the Journal, which was necessitated by paper shortage considerations in 1940, the existence of these Proceedings formed a most valuable precedent for ensuring that papers on wireless were still published separately as Part III of the present-day Journal. It is very clear that as regards the provision of scope and opportunities for publication, no separate society or association could serve its members better than the Institution has done during the past sixteen years and still continues to do in a very satisfactory manner.

Dr. Smith-Rose next referred to the work of the Radio Research Board, with which he has been associated since its establishment in 1920 under the Department of Scientific and Industrial Research. Although concerned mainly with investigations of a fundamental nature, many of the aspects of the Board's programme are determined from time to time by the needs of the defence departments and of the Post Office and B.B.C., each of which has been represented on the Board itself and on all its technical committees. The Board makes its recommendations to the Department of Scientific and Industrial Research, which is responsible for providing the means and facilities for the conduct of the work; in recent years practically the whole programme has been entrusted to the Radio Department of the National Physical Laboratory for execution. Apart from the official reports of the Radio Research Board issued from time to time, the majority of the investigation work has been described in papers and reports published by the Institution of Electrical Engineers and other scientific societies. As an indication of the widespread nature of this publication it may be pointed out that of the 246 papers that have been published in the Proceedings of the Wireless Section during the past sixteen years, no less than eighty of them have been presented by staff working under the auspices of the Radio Research Board.

Little can be said about the recent investigations in hand, since for the past three years the work has been devoted entirely to the furtherance of the prosecution of the radio technical war in the manner in which is considered to be most useful. A conspicuous feature of this recent work has been to realize the fruition in direct Service application of all the long-term investigations sponsored for many years past by the Radio Research Board. The present value of pre-war fundamental work on direction-finding and ultra-short-wave propagation, suitably oriented to meet present conditions, is immediately obvious; but by now most of the apparently more academic subjects under investigation have suddenly been elevated to Service applications of the highest priority. Even some of the research items which had been abandoned in the past as having little or no interest have had to be revived to meet pressing demands, and it is often the fact of having already explored the technique and satisfactorily established the fundamental principles of a particular field that provides the advantage over the enemy in the technical conduct of the war. In some spheres the demand is for basic principles of design of apparatus and equipment which was developed originally as a research tool, and now has to be adapted to more practical application; in other spheres it is accurate measuring equipment and technique that is sought; while in yet other directions the request is for information that will define the present possibilities of radio communication, and more especially what these are likely to be in the immediate future.

\section{AUSTRALIAN ASSOCIATION OF SCIENTIFIC WORKERS}

$T$ HE Australian Association of Scientific Workers called two conferences of scientific workersone in Sydney on February 21-22, and one in Melbourne on March 7-8-to consider the use being made of scientific men in Australia in furthering the war effort.

The Melbourne Conference was attended by about one hundred and thirty members. Industrial undertakings and Government enterprises were almost equally represented; the younger members were in great majority. There was apparent a certain restraint in expressing views, possibly due in part, at least, to the more senior members not giving a lead. There was no doubt at all of the sincere wish to give all services required, but there was apparent deep misgivings whether the Government understood and appreciated what could be done-and can be doneby scientifically trained people given problems to solve; indeed, the opinion was expressed that the scientific men themselves had a duty (1) in seeing for themselves what problems needing immediate solution already existed, (2) in anticipating problems that would inevitably arise, and (3) in suggesting methods of solution and carrying them out. But the doubt was raised whether the Government has confidence in scientific men, or whether it is just a lack of understanding on the part of the scientific men of political methods.

Among the more important problems discussed were : lack of understanding of industrial fatigue ; absence of suitable bodies to study this problem in factories; the inability to make use of experience gained elsewhere; lack of foresight in planning for supplies, especially in agriculture, and in pooling information of plant practices; the wastage of scientifically trained man-power in the Fighting Forces.

It was stated that little or no use is being made of the professional registers; and that the examina- 